\title{
Kelch proteins: emerging roles in skeletal muscle development and diseases
}

\author{
Vandana A Gupta and Alan H Beggs
}

\begin{abstract}
Our understanding of genes that cause skeletal muscle disease has increased tremendously over the past three decades. Advances in approaches to genetics and genomics have aided in the identification of new pathogenic mechanisms in rare genetic disorders and have opened up new avenues for therapeutic interventions by identification of new molecular pathways in muscle disease. Recent studies have identified mutations of several Kelch proteins in skeletal muscle disorders. The Kelch superfamily is one of the largest evolutionary conserved gene families. The 66 known family members all possess a Kelch-repeat containing domain and are implicated in diverse biological functions. In skeletal muscle development, several Kelch family members regulate the processes of proliferation and/or differentiation resulting in normal functioning of mature muscles. Importantly, many Kelch proteins function as substrate-specific adaptors for Cullin E3 ubiquitin ligase (Cul3), a core component of the ubiquitin-proteasome system to regulate the protein turnover. This review discusses the emerging roles of Kelch proteins in skeletal muscle function and disease.
\end{abstract}

Keywords: Kelch, BTB, BACK, Nemaline myopathy, Dystrophy, Congenital myopathy, Cul3, Ubiquitination, Proteasome, Skeletal muscle, Proliferation, Differentiation

\section{Review}

Skeletal muscle development is a highly coordinated process that involves the myogenesis and differentiation of primary myoblasts, and their integrated growth and development into a mature functional organ [1-4]. Consequently, mutations of a large number of proteins associated with development and/or maintenance of skeletal muscle result in disease states. Over the past three decades, tremendous progress has been made in elucidating the genetic basis of muscle diseases. Primary inherited diseases of skeletal muscle include the muscular dystrophies and the non-dystrophic congenital myopathies [5-8]. Muscular dystrophies are characterized by myofiber degeneration with repeated rounds of regeneration that ultimately lead to an end-stage process typified by fibrosis and replacement by adipose tissue $[9,10]$. In contrast, non-dystrophic myopathies exhibit little necrotic or regenerative changes, but muscle biopsies often display characteristic structural changes such as central

\footnotetext{
*Correspondence: beggs@enders.tch.harvard.edu

Division of Genetics and Genomics, The Manton Center for Orphan Disease Research, Boston Children's Hospital, Harvard Medical School, 300 Longwood Ave., Boston, MA 02115, USA
}

cores, nemaline rods, central nuclei, various intracytoplasmic inclusions, or fiber type disproportion, and so on $[10,11]$. Collectively, these diseases are both phenotypically and clinically heterogeneous. Gene discovery in muscle diseases is currently skyrocketing due to the use of nextgeneration sequencing approaches [12-19]. The discovery of new genes is not only crucial for improving diagnostics for these highly heterogeneous muscular disorders, but also is critical for identifying new molecular pathways that may serve as potential therapeutic targets. Recent gene discoveries have identified mutations in Kelch protein genes as the cause of muscle diseases in humans [14,20-22]. Kelch proteins belong to the Kelch superfamily that consists of a large number of structurally and functionally diverse proteins characterized by the presence of a Kelch-repeat domain $[23,24]$. Kelch family members are involved in a number of cellular and molecular processes such as cell migration, cytoskeletal arrangement, regulation of cell morphology, protein degradation, and gene expression [25-31]. This review summarizes our emerging understanding of the various roles of Kelch proteins in skeletal muscle development and disease (Tables 1 and 2). 
Table 1 Kelch family proteins in skeletal muscle development

\begin{tabular}{llll}
\hline Gene & Protein & Function & Expression \\
\hline KLHL19 & KLHL19, KEAP1 & Oxidative stress and insulin signaling in muscle cells [32] & Ubiquitous [33] \\
KLHL31 & KLHL31 & Skeletal and cardiac muscle myogenesis [29,34] & $\begin{array}{l}\text { Skeletal muscle, heart (low levels in } \\
\text { brain, kidney, and liver) [29] }\end{array}$ \\
KLHL39 & KLHL39, IVNS1ABP & Protection against drug-induced cardiomyopathy [35] & Ubiquitous [36] \\
KLHL40 (KBTBD5) & KLHL40 & Skeletal muscle differentiation [14,37] & Skeletal muscle [14] \\
KLHL41 (KBTBD10,KRP1) & KLHL41, Sarcosin & Skeletal muscle differentiation and myofibril assembly [22,38,39] & Skeletal muscle, lungs [22] \\
MKLN1 & MKLN1, Muskelin & Muscle cell adhesion and extracellular communication [40] & Skeletal muscle, brain [40,41] \\
KLHDC1 & KLHDC1 & Muscle cell migration and differentiation [42,43] & Skeletal muscle [42] \\
KLHDC2 & KLHDC2 & Muscle cell migration and differentiation [42,43] & Skeletal muscle [42]
\end{tabular}

\section{Kelch protein superfamily}

The Kelch superfamily includes 66 genes, of which 63 are protein-coding whereas three are non-coding genes. The Kelch protein family is primarily classified into KLHL, KBTBD, and KLHDC subfamilies that differ in the types and numbers of their protein domains (http:// www.genenames.org/) (Figure 1A). A prototypic member of the Kelch family contains an $\mathrm{N}$-terminal BTB/POZ domain, a BACK domain, and two to eight C-terminal Kelch motifs [61]. KLHL subfamily members contain all of these domains whereas the KBTBD subfamily members typically lack the BACK domain [24]. KLHDC subfamily members do not contain either BTB or BACK domains (Figure $1 \mathrm{~B}$ and $1 \mathrm{C}$ ). However, some KLHDC subfamily members do contain alternative domains, such as the transmembrane (KLHDC7A), Glycine rich
(KLHDC10), Lish and CTLH (MKLN1) domains, in addition to traditional Kelch repeats.

A phylogenetic analysis of human Kelch family proteins shows that most members within each subfamily largely cluster together with the KLHDC subfamily, that lacks BTB and BACK domains, apparently having diverged first (Figure 2A). However, several members are clustered with other subfamilies suggesting that some gain or loss of BTB or BACK domains may have occasionally occurred at later stages of evolution. Kelch proteins bind to specific substrates through their Kelch domains. An amino acid alignment of only the Kelch repeat regions shows that proteins involved in similar disease processes are clustered together (for example, KLHL40, KLHL41, and KBTBD13, all of which cause nemaline myopathy) (Figure 2B). This suggests that

Table 2 Kelch family proteins in human diseases

\begin{tabular}{|c|c|c|}
\hline Gene & Function & Expression \\
\hline \multicolumn{3}{|c|}{ Neuromuscular diseases } \\
\hline$K L H L 1$ & Spinocerebellar ataxia type 8 [44] & Brain, prostate, small intestine, colon [44] \\
\hline KLHL9 & Distal myopathy [20] & Ubiquitous [20] \\
\hline KLHL16 (GAN) & Giant axonal neuropathy [45] & Brain, skeletal muscle, heart, kidney, liver [46] \\
\hline KLHL40 (KBTBD5) & Severe nemaline myopathy with fetal akinesia $[14,37]$ & Skeletal muscle [14] \\
\hline KLHL41 (KBTBD10) & Nemaline myopathy $[22,38,39]$ & Skeletal muscle, lungs [22] \\
\hline KBTBD13 & Nemaline myopathy with cores [21] & Skeletal muscle, lungs, heart [21] \\
\hline \multicolumn{3}{|l|}{ Cancer } \\
\hline KLHL6 & Chronic lymphocytic leukemia [47] & Lymphocytes (unknown in other tissues) [48] \\
\hline KLHL19 (KEAP1) & Pulmonary papillary adenocarcinoma [49] & Ubiquitous [50] \\
\hline KLHL20 & Prostate cancer progression [51] & Ubiquitous [52] \\
\hline KLHL37 (ENC1) & Brain tumors [53] & Brain (unknown in other tissues) [54] \\
\hline$K L H D C 8 B$ & Hodgkin's lymphoma [55] & Unknown \\
\hline \multicolumn{3}{|c|}{ Other Inherited Diseases } \\
\hline KLHL3 & Pseudohypoalsosteronism type II [56] & $\begin{array}{l}\text { Cerebellum, kidney, spinal cord, heart, } \\
\text { lung, placenta, testis, arota [56] }\end{array}$ \\
\hline$K L H L 7$ & Autosomal dominant retinitis pigmentosa [57] & Ubiquitous [57] \\
\hline KLHL10 & Oligozoospermia [58,59] & Testis [60] \\
\hline
\end{tabular}



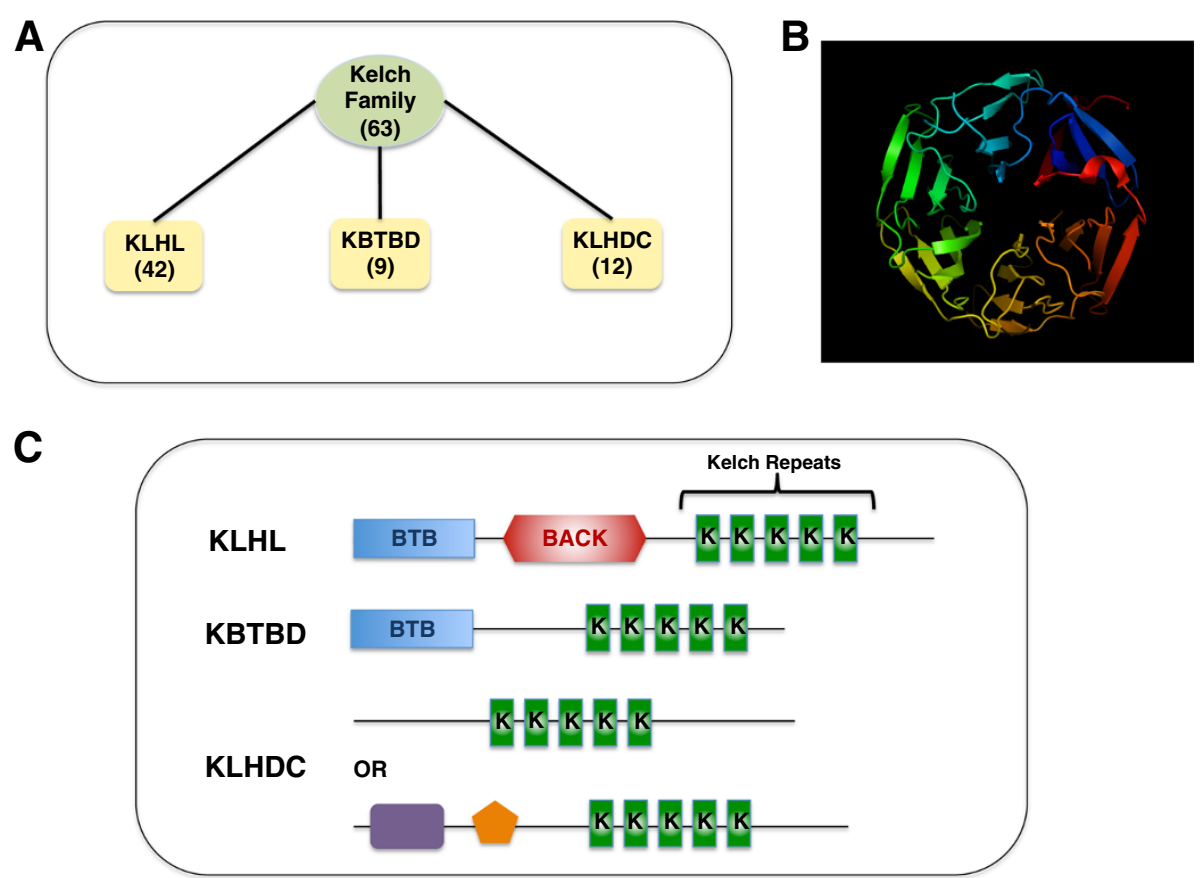

Figure 1 The Kelch Superfamily. (A) The Kelch family consists of 63 proteins that are subclassified in to KLHL, KBTBD and KLHDC subfamilies. (B) Structure of Kelch domain of rat KLHL41 (PDB code 2WOZ) comprising six repeats that form the complete Kelch domain. The structure was generated using PyMOL (www.pymol.org). (C) Prototype members of different subfamilies showing different domain organization. KLHL proteins have an N-terminal BTB/POZ, a BACK and C-terminal Kelch repeats. KBTBD proteins contain an N-terminal BTB domain and Kelch repeats. The BACK domain is normally absent in KBTBD proteins. KLHDC proteins lack both BTB/POZ and BACK domains and contain either Kelch repeats alone or with other domains such as transmembrane (for example, KLHDC7A), Glycine rich (for example, KLHDC10), or Lish and CTLH domains (for example, MKLN1).

Kelch domains with high sequence homology may be regulating similar biological processes through interactions with shared or related binding partners. Under this model, functional differences between these related Kelch family members will likely derive from variation in other domains of the proteins.

\section{BTB/POZ domain}

The BTB/POZ domain derives its name from the Drosophila Bric-a-brac, Tramtrac, and Broad complex due to sequence homology $[62,63]$. As the DNA poxvirus in which this domain was first identified also showed some similarity to zinc finger proteins, this domain was concurrently named the POZ (Poxvirus and Zinc finger) domain. BTB domains are mainly involved in facilitating selfoligomerization or mediating protein-protein interactions with other proteins $[64,65]$. Despite the similar secondary structures and shared organization of BTB proteins, their primary sequences are not well conserved. This sequence variability between BTB proteins contributes to differential protein-protein interactions and results in different functional roles. BTB domains are also present in other non Kelch-repeat containing proteins. The major difference lies in the protein interactors of BTB domains in Kelch versus non-Kelch proteins. In the Kelch family, the most important known interactive role of the BTB domain is to act as an adaptor between E3 ubiquitin ligases and Kelch domains in order to form active ubiquitination complexes [66-68]. In non-Kelch families of proteins, BTB protein-regulated interactions typically involve recruitment of co-activators or repressors to transcription complexes. In addition, these interacting proteins are also involved in cytoskeletal arrangement and ion conductance [69-72].

\section{BACK domain}

The BACK domains found in KLHL subfamily members are the most conserved domain of the Kelch family and are present between the $\mathrm{N}$-terminal BTB and C-terminal Kelch domains. BACK domains contain an $\mathrm{N}$-terminal conserved Asn-Cys-Leu-Gly-Ile motif and a Val-Arg-[Leu/Met/Phe]Pro-Leu-Leu sequence, two arginines, four glutamic acids, and several hydrophobic positions causing them to be hydrophobic in nature [61]. The true role of the BACK domain is not known, but it is predicted to participate in BTB-E3 ubiquitin ligase complex formation [61]. Evidence for the functional significance of BACK domains comes from recent studies where missense mutations in this domain in KLHL40 and KLHL41 are pathogenic in human patients affected with nemaline myopathy $[14,22]$. 


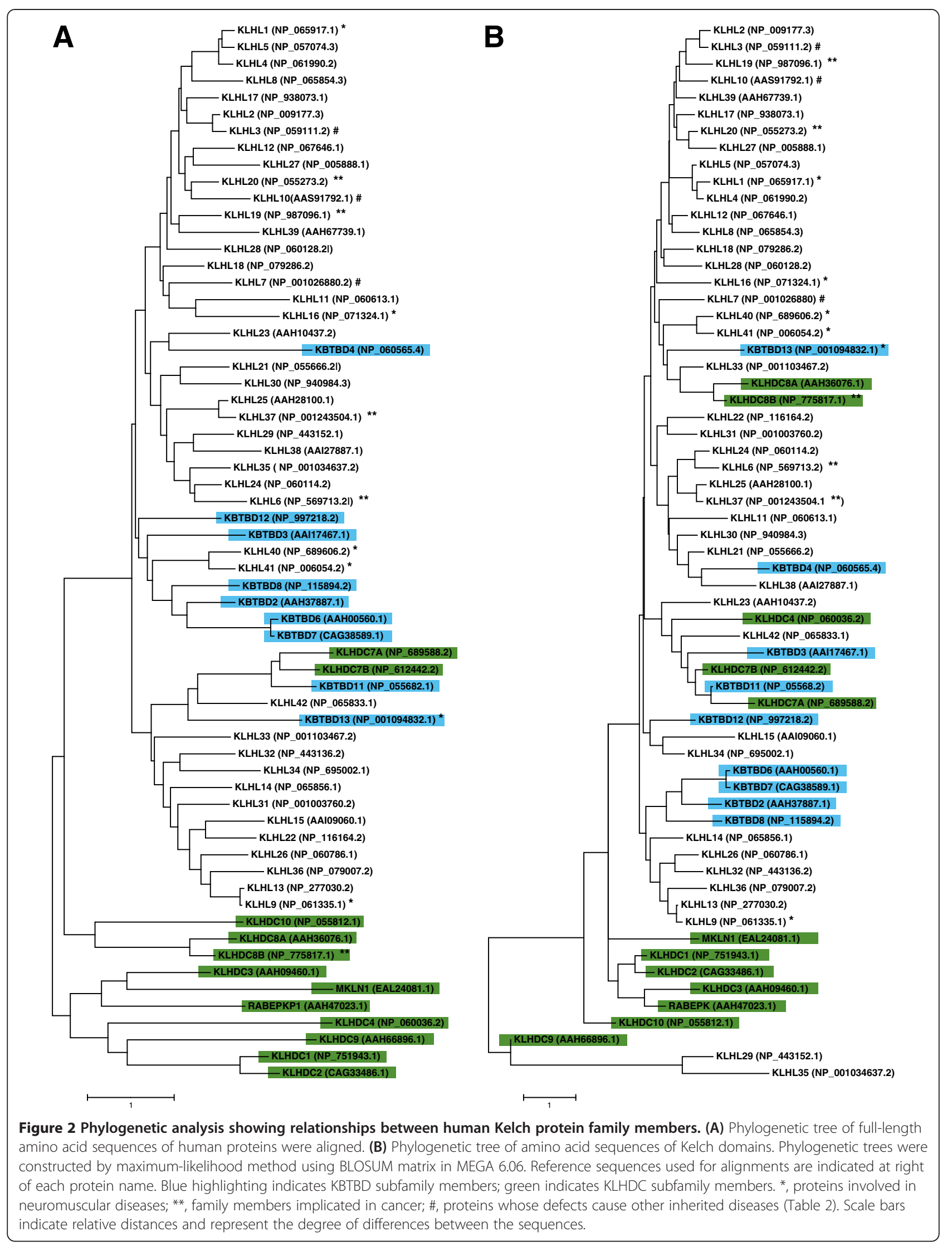




\section{Kelch domain}

Kelch motifs range from 44 to 56 amino acids in length and are usually arranged in a series of five to seven repeats in most of the family members [23]. The signature motifs in each Kelch repeat are a series of four hydrophobic amino acids followed by glycine doublet, a conserved tyrosine, and a conserved tryptophan. Each Kelch repeat folds into four twisted antiparallel $\beta$-strands connected by intrablade loops to form a single blade of a $\beta$-propeller (Figure 1B). A C-terminal strand closure mechanism links the first and last blades to complete the propeller. Kelch $\beta$-propellers primarily function as scaffolds for proteinprotein interactions. Despite the shared tertiary structure, there is little primary sequence identity between one Kelch repeat and another, suggesting a wide diversity of interacting partners across the Kelch superfamily. In nemaline myopathy, all pathogenic KBTBD13 mutations identified to date in human patients were found in the Kelch repeats [21]. Similarly, mutations in Kelch repeats of both KLHL4O or KLHL41 also result in nemaline myopathy [14,22].

\section{Kelch proteins in skeletal muscle diseases KLHL9}

The first Kelch protein defect reported in a primary skeletal muscle disease was of KLHL9, resulting in an early onset autosomal dominant form of distal myopathy [20]. Distal myopathies are a heterogeneous group of muscle diseases characterized by progressive muscular atrophy and weakness, beginning in distal (hence the name) and progressing to proximal limb muscles [73]. By linkage analysis and subsequence candidate sequencing, Cirak et al. identified a p.Leu95Phe missense change in the N-Terminal BTB domain of KLHL9 in several affected members of a single large German family with a dominant form of distal myopathy [20]. Leucine is conserved at this position in other vertebrates, and molecular modeling predicted that the change to phenylalanine would affect BTB domain conformation and likely disrupt the protein-protein interactions with $\mathrm{Cul} 3$ ubiquitin ligase. Cell culture studies subsequently showed that wild-type KLHL9 interacted with Cul3 ubiquitin ligase whereas the p.Leu95Phe mutation disrupted the KLHL9-Cul3 interaction [20,74]. The Kelch family members act as substrate-recognizing adaptors of the Cul3 ubiquitination complex, which targets specific substrates for ubiquitination and subsequent degradation by proteasomal pathways. While experimental evidence for KLHL9 as a regulator of ubiquitination in skeletal muscles is still lacking, one potential substrate for KLHL9 action is postulated to be Aurora B kinase [20]. Previous studies have shown that KLHL9 targets this kinase during mitotic progression and cytokinesis [75]. Aurora B kinase is a regulator of assembly and disassembly of type III intermediate filaments including vimentin, desmin, and type
IV neurofilaments. Therefore, a mis-regulation of Aurora B Kinase function in KLHL9 deficiency is postulated to affect normal skeletal muscle function [76].

\section{KBTBD13}

KBTBD13 is a member of the KBTBD subfamily of Kelch proteins that contains a BTB domain and Kelch repeats but lacks a BACK domain. KBTBD13 mutations result in an autosomal dominant form of nemaline myopathy associated with cores in affected patients [21]. Clinically, patients with KBTBD13 mutations exhibit poor exercise tolerance, gait abnormality, and progressive weakness of the neck and proximal limb muscles. The peculiar clinical feature specific to KBTBD13 patients that is not seen in other forms of congenital myopathies is a characteristic slowness of movement, where patients are unable to run and correct themselves from falling over. Moreover, skeletal muscles of patients with KBTBD13 mutations exhibit cores that lack oxidative enzymatic activity and show predominance as well as hypertrophy of type 1 (slow) myofibers [21]. The localization of KBTBD13 in myofibers is not clear. Localization studies have shown that KBTBD13 does not co-localize with $\alpha$-actin (thin filament protein) or $\alpha$-actinin (a Z-line marker), suggesting a different localization and mechanism of action than previously known proteins in nemaline myopathy, which primarily localize to thin filaments [21]. All known pathogenic mutations in KBTBD13 are localized in the Kelch repeats of the protein and are predicted to damage the $\beta$-propeller blades. KBTBD13 forms a complex with Cul3 ubiquitin ligase through its N-terminal BTB domain and this interaction is required for the formation of a functional Cul3 ubiquitin ligase complex, suggesting that the pathogenic mechanism in KBTBD13-related nemaline myopathy may involve dysregulation of cellular protein ubiquitination [66].

\section{KLHL40}

KLHL40 mutations have been recently identified as a cause of nemaline myopathy in a severe form of the disease [14]. KLHL40 belongs to the KLHL subfamily of Kelch proteins that contain an N-terminal BTB domain, a BACK domain, and five Kelch repeats on the $\mathrm{C}$-terminal end. Recessive mutations in KLHL4O are associated with fetal akinesia or hypokinesia during the prenatal period, respiratory failure, and swallowing difficulty at birth, as well as contractures, fractures, and dysmorphic features that in many cases are associated with early death. A significant number of patients with KLHL40 mutations (approximately 17\%) also exhibit ophthalmoparesis that is usually not present in other genetic subtypes of nemaline myopathy. Moreover, 
fractures are also a relatively frequent presentation in KLHL4O patients that is not commonly seen in other forms of nemaline and other congenital myopathies. Mutations of KLHL4O have been found in exons encoding all domains of the protein with a majority of the mutations seen in the Kelch repeats, including a founder mutation (p.Glu528Lys) present in Japanese, Turkish, and Kurdish populations. Both truncating as well as missense mutations are seen in KLHL40. Knockdown of KLHL4O orthologues in zebrafish results in sarcomeric abnormalities and impaired locomotion similar to human patients, providing further evidence that KLHL4O is the disease-causing gene in nemaline myopathy [14]. Murine Klhl40 protein is localized at triads along with the sarcoplasmic reticulum (SR) marker Ryr1 [22]. KLHL40 interacts with CUL3 ubiquitin ligase via the $\mathrm{N}$-terminal BTB domain and forms a protein complex, the functional significance of which remains to be unraveled [68]. Recent work has also shown that Klhl40 promoter is a direct target of myoD and is crucial for muscle cell differentiation [22,37].

\section{KLHL41}

KLHL41 is the most recent member of the Kelch family to be implicated in muscle disease. Unlike KLHL9 and KBTBD13 mutations that cause a dominant form of the disease, mutations in KLHL41, like KLHL4O, result in an autosomal recessive form of nemaline myopathy. Genetic analysis of five unrelated families has shown that KLHL41 mutations appear to follow a genotypephenotype correlation. Mutations that led to truncated proteins resulted in a severe form of the disease with fetal akinesia, a lack of antigravity movement, arthrogryposis, and dislocation of the hip and knees. These patients died within the first few months of life due to respiratory insufficiency. Missense changes resulted in a mild or intermediate form of the disease with impaired motor functions and survival into late childhood and/or early adulthood. KLHL41 localizes in the perinuclear area and over (but not within) I bands, in association with the terminal cisternae and longitudinal vesicles of the SR membranes present in the I-band area at the triadic regions. As most of the previously known NM proteins are components of sarcomeric thin filaments, the unique localization of KLHL41, as well as nonsarcomeric localization of KLHL40 in association with the triads, suggests the involvement of new pathophysiological mechanisms for nemaline myopathy [77]. Knockdown of KLHL41 in zebrafish resulted in skeletal muscle myopathy with disorganized and thinner myofibers as well as reduced motor function in comparison to wildtype zebrafish. Interestingly, morphant fish also exhibited numerous electron dense structures in skeletal muscle, reminiscent of small or nascent nemaline bodies, in addition to Z-line thickening as seen in human nemaline myopathy patients.

Previous studies have shown that KLHL41 interacts with Cul3 ubiquitin ligase to form functional ubiquitination complexes with proteins targeted for degradation [78]. The identification of protein substrates targeted by the KLHL41-Cul3 ubiquitin complex is not known. KLHL41 interacts with nebulin [79] and co-localizes with actin [80], mutations of which cause approximately $65 \%$ to $70 \%$ of all known mutations in patients affected with nemaline myopathy [81]. The high degree of sequence similarity between Kelch repeats of KBTBD13, KLHL40, and KLHL41 suggests that they may share identical or closely related binding partners whose dysregulation leads to nemaline myopathy through a common final pathway and implicates a critical role for BTB-Kelch family members in the maintenance of sarcomeric integrity in skeletal muscle.

\section{Kelch proteins in skeletal muscle development}

Members of the Kelch family are known to be involved in multiple biological processes such as migration, cytoskeletal arrangement, regulation of cell morphology, myofibril assembly, protein degradation, and gene expression $[25,27,45,80,82,83]$. Several Kelch proteins associate with the actin cytoskeleton via the $\beta$-propeller module, and these associations are important for functional roles of these proteins $[84,85]$. Other Kelch proteins affect the organization of cytoskeletal, plasma membrane, or organelle structures but do not bind directly to or co-localize with actin.

In skeletal muscle, many Kelch proteins are known to regulate the proliferation as well as differentiation of muscle cells. KLHL41 is highly expressed in myoblasts during early muscle differentiation [86]. Knockdown as well as overexpression of KLHL41 in C2C12 cells inhibited myoblast differentiation, suggesting a role in cell cycle exit and the promotion of differentiation [38]. Knockdown of KLHL41 in cultured cardiomyocytes affected lateral fusion of myofibrils resulting in thin myofibrils [39]. In developing chicken and zebrafish embryos, KLHL31 is specifically expressed in early heart and in developing myoblasts shortly after their commitment to this fate, signifying an important role during skeletal muscle and cardiac myogenesis [29]. The expression of KLHL31 is initiated just after MyoD in developing skeletal muscles and this expression persisted in later stages of development implying the possible involvement of KLHL31 in the early phases of myogenic commitment and during later muscle differentiation [34]. KLHL31 acts as a transcriptional repressor in the MAPK/JNK signaling pathway in mouse cardiomyocytes. In skeletal muscle cells, overexpression of KLHDC2 rendered these cells unable to respond to chemoattractants 
and led to augmented stress fiber formation and cell adherence [26]. Additionally, myoblasts overexpressing KLHDC2 failed to differentiate into mature myotubes. KLHDC2 also regulates transcription processes by inducing expression of the leucine zipper transcription factor (LZIP) in muscle cells. KLHDC1 is a paralogue of KLHDC2 and shares 50\% similarity with KLHDC2. Similar to KLHDC2, the highest expression of KLHDC1 is observed in skeletal muscles [42]. However, the functional roles of KLHDC1 remain unknown. Muskelin (MKLN1, a KLHDC subfamily member) was identified in an expression cloning screen for molecules that promoted cell adhesion to the extracellular matrix component thrombospondin 1. Overexpression or antisense depletion of muskelin in mouse skeletal myoblasts correlates with altered organization of fascin microspikebased adhesive contacts and a redistribution of focal contact in TSP-1 adherent cells, yet has modest effects on actin organization in cells adherent on fibronectin [40]. These results suggest that muskelin functions at a node point in the integration of cell responses to complex extracellular matrix. As most of muskelin is cytoplasmic, its effects on matrix contacts are thought to be mediated indirectly. The requirement of Kelch proteins in cell morphology comes from yeast-based studies where mutations in Kelch proteins resulted in cell fusion defects [87]. The emerging roles of Kelch proteins in metabolic pathways come from a recent study where Keap1 (Klhl19) knockout mice exhibited a significant reduction in insulin signaling pathway gene expression in skeletal muscles $[32,88,89]$. Keap1 also regulates redox signaling, as increased oxidative stress thought to be associated with its dysregulation is observed in sedentary elderly people [89]. Nd1-L (KLHL39) is an actin binding protein expressed in high levels in heart that protects against doxorubicin-induced cardiomyopathy in mice [35].

\section{Molecular pathways regulated by Kelch proteins}

Detailed studies on molecular functions of Kelch proteins are still largely lacking except with regard to their roles as substrate specific adaptors in the ubiquitination pathways, thereby regulating diverse cellular processes [21,28,90-94]. Skeletal muscle proteins are especially prone to wear and tear as they are the primary force generating mechanism in skeletal muscle. A quality control check, by removal of damaged proteins and coordinated turnover, is performed by many proteolytic systems in skeletal muscles: the caspase and calpain systems of partially muscle-specific proteases; the ubiquitin proteasome system (UPS) which degrades polyubiquitinated proteins via the $26 \mathrm{~S}$ proteasome; and the autophaghy pathway which removes proteins by inclusion in autophagic/ lysosomal vesicles [95-104]. Kelch proteins function by acting as substrate specific adaptors for the Cullin3- dependent E3 ubiquitination ligase complex during protein ubiquitination $[93,105,106]$.

Ubiquitination is a multistep process in which an E1 ubiquitination activating enzyme transfers ubiquitin to an E2 ubiquitin-conjugating enzyme. The final step of this process is the ligation of ubiquitin to the substrate, catalyzed by an E3 ubiquitin protein ligase [107-109]. As the stability of a large number of proteins is controlled by the ubiquitin system, it is crucial to determine how the cell achieves sufficient diversity among E3s so that each one selectively recognizes only one or a few substrates in the sea of cellular proteins present at any time. Several hundreds of such E3 ligases are described, some of which are clearly specific to skeletal muscles $[110,111]$. One subgroup of E3 ligases are the ubiquitously expressed cullins that do not bind to their substrates directly, but rely on an array of adaptor proteins. There are seven cullin genes known in mammals (CUL1-CUL3, CUL4a, CUL4b, CUL5, and CUL7), but only CUL3 interacts with the BTB-Kelch proteins [112]. Thus, BTB-domain proteins serve as the substrate specific adaptors of CUL3-based E3 ubiquitin ligases [113]. The crucial requirement of CUL3 function is evident from Cul3 null mice that exhibit embryonic lethality. In particular, Cul3 null homozygous mice exhibit abnormal cycling of cells in extraembryonic membranes, reduced size, abnormal gastrulation and trophoblast cells, absence of an amnion, and death by embryonic day 7.5 [114]. In humans, dominant CUL3 mutations are associated with pseudohypoaldosteronism type II, a genetic disorder causing hypertension, hyperkalemia, and metabolic acidosis [92]. Even though CUL3 is ubiquitously expressed, the functional specificity of CUL3 in different spatial and developmental contexts is exhibited through protein-protein interaction with different Kelch proteins. This may in part be regulated by tissue specific expression, and substrate specificity of the different Kelch protein-binding partners. KLHL40 and KLHL41 are primarily expressed in skeletal (with low expression in cardiac) muscles. In skeletal muscles, deficiency of these proteins and thereby a perturbation of $\mathrm{Cul} 3$ ubiquitin complex formation to regulate the protein turnover of specific substrates may lead to skeletal muscle diseases.

The regulation of ubiquitination by Kelch proteins in skeletal muscles has been investigated in the context of disease. Kelch proteins such as KLHL9, KBTBD13, KLHL40, and KLHL41 that cause skeletal muscle disorders, each form protein complexes with CUL3 $[20,66,68,78]$. The functional significance of these interactions has been shown by several studies, as Cul3-KLHL41 and Cul3KBTBD13 complexes are able to perform in vitro ubiquitination in the presence of other members of the functional ubiquitination complex [66,78]. Moreover, in distal myopathy, the interaction of mutant KLHL9 with Cul3 is highly 
reduced in comparison to wild-type KLHL9, which may in turn affect the ubiquitination of cellular proteins [20]. Identifying the protein interactors of each of these Kelch proteins in skeletal muscle will provide further insight into disease mechanisms. A study of the skeletal muscle interactome showed that KLHL41 interacts with TCAP, ENO3, and SGCG, three proteins encoded by genes mutated in limb-girdle muscular dystrophy type $2 \mathrm{G}$, metabolic myopathy, and limb-girdle muscular dystrophy type $2 \mathrm{C}$, respectively [79]. This points toward the potential regulatory roles of Kelch proteins and/or ubiquitination pathways in other muscle diseases as well [79,115-117]. KLHL41 also interacts with nebulin, a known causative gene of nemaline myopathy, by protein-protein interactions and is co-localized with actin at the tips of pseudopodia in fibroblasts. These data suggest that KLHL41 and other diseasecausing Kelch proteins KLHL40, KBTBD13, and KLHL9 may contribute to disease pathogenesis by regulating the protein turnover of nebulin, actin, and other important skeletal muscle proteins that are required for normal functioning of skeletal muscle (Figure 3). In the absence of Kelch proteins, disturbance of this protein turnover process and subsequent overabundance of damaged sarcomeric proteins may result in disease states in affected muscles (Figure 3). In addition to protein degradation, ubiquitination has non-degradative roles such as modulation of protein activity, interaction, and sub-cellular localization of proteins $[118,119]$, so it may be that some of these Kelch proteins actually promote the stability of their binding partners. Future studies will help us to better understand these processes in the context of skeletal muscle development and diseases.

\section{Kelch proteins in other human diseases}

A number of Kelch proteins play important roles in a variety of human diseases, including cancer and neurological disorders [55,120-122] (Table 2). Mutations of KLHL6, KLHL19, KLHL20, and KLHL37 are associated with various forms of cancers $[47,49,51,53]$. Whole exome sequencing in a rare genetic disorder, pseudohypoalsosteronism type II, involving hypertension, hyperkalemia, and metabolic acidosis, recently identified mutations in the KLHL3 gene [56,92]. KLHL3 mutations are either recessive or dominant in nature. The recessive mutations are distributed throughout the encoded protein, whereas dominant mutations were localized in the cullin binding sites, likely impairing the formation of active Cul3 complexes. Linkage analysis and mutation screening in 502 retinopathy probands identified KLHL7 as a cause of autosomal dominant
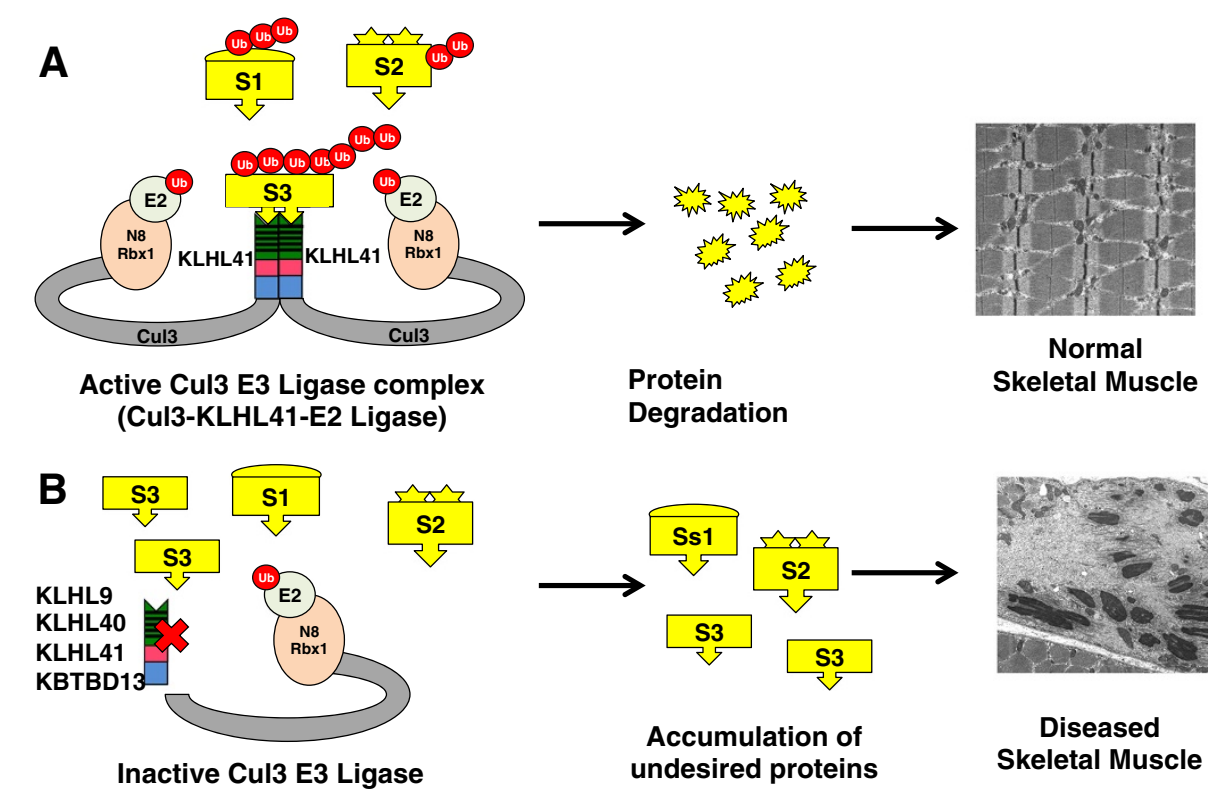

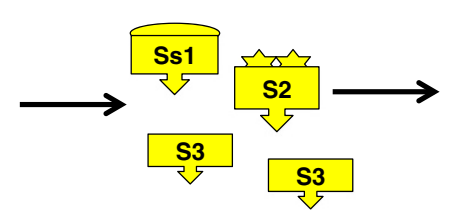

Accumulation of undesired proteins

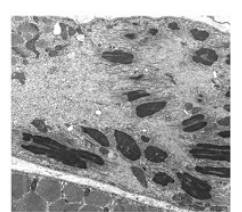

Diseased Skeletal Muscle

Figure 3 Kelch proteins act as a substrate specific adaptors for E3-ubiquitinin protein complex. (A) Cullin3 complex is Nedd8 (N8) modified and recruits E2-bound ubiquitin through RING-finger protein Rbx1. The assembly of a functional ubiquitination complex requires the binding of Cul3-E2 complex to substrate specific Kelch adaptor proteins. Cul3 directly binds to N-terminal BTB domain of Kelch protein and this E3-ubiquitination complex interacts with substrates (for example, S1, S2, S3) by C-terminal Kelch-repeat containing domains of Kelch proteins, causing ubiquitination of the target proteins and subsequent degradation (or stabilization and so on) by the proteasome system. This results in normal protein turnover of proteins required for normal functioning of muscle resulting in healthy skeletal muscles. (B) The deficiency of Kelch proteins (such as disease causing KLHL9, KLHL40, KLHL41, and KBTBD13) prevents the assembly of functional Cullin3 ubiquitination complex thereby perturbing the protein turnover process. In the model shown here, this results in accumulation of abnormal proteins (for example, S1, S2, S3) leading to unavailability of normal proteins in skeletal muscle leading to a diseased state. 
retinitis pigmentosa [57]. Interestingly, the missense mutations localized in the BACK domain of the KLHL7 protein were predicted to affect the ubiquitination complexes [57]. KLHL10 is specifically expressed in testis and mutations of this gene lead to oligozoospermia and male infertility. Missense changes in KLHL10 impair homodimerization that is required for normal protein function, resulting in functional deficiency in patients [58]. Spinocerebellar ataxia type 8 (SCA8) is a dominantly inherited disorder caused by large CTG repeat expansions in the untranslated antisense RNA of the KLHL1 gene [123]. While the molecular disease mechanism is still unclear, reduction of KLHL1 in mice leads to the degeneration of Purkinje cell function, suggesting a significant role in the pathophysiology of SCA8 [124]. Giant axonal neuropathy (GAN) is a rare autosomal recessive progressive neurodegenerative disorder involving the peripheral and central nervous systems. A number of mutations in gigaxonin $(G A N)$, a BTBKelch protein, have been identified as resulting in a generalized disorganization of cytoskeletal intermediate filaments $[45,125]$. This cytoskeletal disorganization is attributed to an accumulation of abnormal proteins that are normally degraded by ubiquitinin-proteasome pathway in gigaxonin deficiency [126]. Collectively, these observations suggest that similar molecular pathways may be involved in the pathophysiology of a variety of diseases caused by abnormalities of Kelch proteins.

\section{Conclusions}

Recent developments in gene discovery have led to the identification of Kelch family members as regulators of skeletal muscle development and function. We are still in the early stages of fully understanding the molecular pathways regulated by these proteins. Nonetheless, the discovery of these proteins in skeletal muscle diseases and function is very exciting, both in terms of improving diagnostics and opening up new directions of research on cellular and molecular pathways crucial for skeletal muscle function. Further studies on ubiquitination and the identification of Kelch substrates in skeletal muscle will help us to develop suitable therapeutics for a wide range of muscle diseases and related disorders.

\section{Competing interests}

The authors declare that they have no competing interests.

\section{Authors' contribution}

VAG and AHB wrote the manuscript. Both authors read and approved the final manuscript.

\footnotetext{
Authors' information

Alan H Beggs, PhD is Sir Edwin and Lady Manton Professor of Pediatrics at Harvard Medical School and Research Associate in the Division of Genetics and Genomics at Boston Children's Hospital where he is also director of The Manton Center for Orphan Disease Research. Dr. Beggs' research is focused on developing approaches to diagnose and treat congenital myopathies and
}

related neuromuscular diseases. Dr. Beggs has been associated with the discovery of several new genes associated with congenital muscle diseases as well as developing gene and protein based therapies for X-linked myotubular myopathy.

Vandana A Gupta, PhD is an Instructor in Pediatrics at Harvard Medical School and Associate Research Staff in the Division of Genetics and Genomics at Boston Children's Hospital. Dr. Gupta has identified several new genes in congenital muscle diseases using zebrafish and human studies. Dr. Gupta has been awarded many fellowships and conference awards and is currently supported by a K01 AR062601 from the National Institute of Arthritis and Musculoskeletal and Skin Diseases of National Institutes of Health and Charles H. Hood Child Health Grant Foundation.

\section{Acknowledgements}

VAG is supported by K01 AR062601 from the National Institute of Arthritis and Musculoskeletal and Skin Diseases of National Institutes of Health and a Charles H. Hood Foundation Child Health Research Grant. This work is supported by the Muscular Dystrophy Association of USA (MDA201302), National Institutes of Health grant from the National Institute of Arthritis and Musculoskeletal and Skin Diseases R01 AR044345; the AUism Charitable Foundation, and A Foundation Building Strength (to AHB).

Received: 26 March 2014 Accepted: 6 May 2014

Published: 1 June 2014

\section{References}

1. Jansen KM, Pavlath GK: Molecular control of mammalian myoblast fusion. Methods Mol Biol 2008, 475:115-133.

2. Bentzinger CF, Wang YX, Rudnicki MA: Building muscle: molecular regulation of myogenesis. Cold Spring Harb Perspect Biol 2012, 4:a008342.

3. Braun T, Gautel M: Transcriptional mechanisms regulating skeletal muscle differentiation, growth and homeostasis. Nat Rev Mol Cell Biol 2011, 12:349-361.

4. Mok GF, Sweetman D: Many routes to the same destination: lessons from skeletal muscle development. Reproduction 2011, 141:301-312.

5. Mercuri E, Muntoni F: Muscular dystrophies. Lancet 2013, 381:845-860.

6. Bertini E, D'Amico A, Gualandi F, Petrini S: Congenital muscular dystrophies: a brief review. Semin Pediatr Neurol 2011, 18:277-288.

7. Nance JR, Dowling JJ, Gibbs EM, Bonnemann CG: Congenital myopathies: an update. Curr Neurol Neurosci Rep 2012, 12:165-174.

8. Rahimov F, Kunkel LM: The cell biology of disease: cellular and molecular mechanisms underlying muscular dystrophy. J Cell Biol 2013, 201:499-510.

9. Sewry CA: Muscular dystrophies: an update on pathology and diagnosis. Acta Neuropathol 2010, 120:343-358.

10. Sewry CA: Pathological defects in congenital myopathies. J Muscle Res Cell Motil 2008, 29:231-238.

11. North KN, Wang CH, Clarke N, Jungbluth $H$, Vainzof M, Dowling JJ, Amburgey K, Quijano-Roy S, Beggs AH, Sewry C, Laing NG, Bonnemann CG, International Standard of Care Committee for Congenital Myopathies: Approach to the diagnosis of congenital myopathies. Neuromuscul Disord 2014, 24:97-116.

12. Torella A, Fanin M, Mutarelli M, Peterle E, Del Vecchio BF, Rispoli R, Savarese M, Garofalo A, Piluso G, Morandi L, Ricci G, Siciliano G, Angelini C, Nigro V: Next-generation sequencing identifies transportin 3 as the causative gene for LGMD1F. PLoS One 2013, 8:e63536.

13. Stevens E, Carss KJ, Cirak S, Foley AR, Torelli S, Willer T, Tambunan DE, Yau S, Brodd L, Sewry CA, Feng L, Haliloglu G, Orhan D, Dobyns WB, Enns GM, Manning M, Krause A, Salih MA, Walsh CA, Hurles M, Campbell KP, Manzini MC, UK10K Consortium, Stemple D, Lin YY, Muntoni F: Mutations in B3GALNT2 cause congenital muscular dystrophy and hypoglycosylation of alpha-dystroglycan. Am J Hum Genet 2013, 92:354-365.

14. Ravenscroft G, Miyatake S, Lehtokari VL, Todd EJ, Vornanen P, Yau KS, Hayashi YK, Miyake N, Tsurusaki Y, Doi H, Saitsu H, Osaka H, Yamashita S, Ohya T, Sakamoto Y, Koshimizu E, Imamura S, Yamashita M, Ogata K, Shiina M, Bryson-Richardson RJ, Vaz R, Ceyhan O, Brownstein CA, Swanson LC, Monnot S, Romero NB, Amthor H, Kresoje N, Sivadorai P, et al: Mutations in $\mathrm{KLHL} 40$ Are a frequent cause of severe autosomal-recessive nemaline myopathy. Am J Hum Genet 2013, 93:6-18.

15. Carss KJ, Stevens E, Foley AR, Cirak S, Riemersma M, Torelli S, Hoischen A, Willer T, van Scherpenzeel M, Moore SA, Messina S, Bertini E, Bonnemann CG, Abdenur JE, Grosmann CM, Kesari A, Punetha J, Quinlivan R, Waddell LB, 
Young HK, Wraige E, Yau S, Brodd L, Feng L, Sewry C, MacArthur DG, North KN, Hoffman E, Stemple DL, Hurles ME, et al: Mutations in GDP-mannose pyrophosphorylase B cause congenital and limb-girdle muscular dystrophies associated with hypoglycosylation of alpha-dystroglycan. Am J Hum Genet 2013, 93:29-41.

16. Majczenko K, Davidson AE, Camelo-Piragua S, Agrawal PB, Manfready RA Li X, Joshi S, Xu J, Peng W, Beggs AH, Li JZ, Burmeister M, Dowling JJ: Dominant mutation of CCDC78 in a unique congenital myopathy with prominent internal nuclei and atypical cores. Am J Hum Genet 2012, 91:365-371.

17. Melia MJ, Kubota A, Ortolano S, Vilchez JJ, Gamez J, Tanji K, Bonilla E, Palenzuela L, Fernandez-Cadenas I, Pristoupilova A, Garcia-Arumi E, Andreu AL, Navarro C, Hirano M, Marti R: Limb-girdle muscular dystrophy $1 \mathrm{~F}$ is caused by a microdeletion in the transportin 3 gene. Brain 2013, 136:1508-1517.

18. Boyden SE, Mahoney LJ, Kawahara G, Myers JA, Mitsuhashi S, Estrella EA, Duncan AR, Dey F, DeChene ET, Blasko-Goehringer JM, Bonnemann CG, Darras BT, Mendell JR, Lidov HG, Nishino I, Beggs AH, Kunkel LM, Kang PB: Mutations in the satellite cell gene MEGF10 cause a recessive congenital myopathy with minicores. Neurogenetics 2012, 13:115-124.

19. Manzini MC, Tambunan DE, Hill RS, Yu TW, Maynard TM, Heinzen EL, Shianna KV, Stevens CR, Partlow JN, Barry BJ, Rodriguez J, Gupta VA, Al-Qudah AK, Eyaid WM, Friedman JM, Salih MA, Clark R, Moroni I, Mora M, Beggs AH, Gabriel SB, Walsh CA: Exome sequencing and functional validation in zebrafish identify GTDC2 mutations as a cause of Walker-Warburg syndrome. Am J Hum Genet 2012, 91:541-547.

20. Cirak S, von Deimling F, Sachdev S, Errington WJ, Herrmann R, Bonnemann C, Brockmann K, Hinderlich S, Lindner TH, Steinbrecher A, Hoffmann K, Prive GG, Hannink M, Nurnberg P, Voit T: Kelch-like homologue 9 mutation is associated with an early onset autosomal dominant distal myopathy. Brain 2010, 133:2123-2135.

21. Sambuughin N, Yau KS, Olive M, Duff RM, Bayarsaikhan M, Lu S, Gonzalez-Mera L, Sivadorai P, Nowak K, Ravenscroft G, Mastaglia FL, North KN, Ilkovski B, Kremer H, Lammens M, van Engelen BG, Fabian V, Lamont P, Davis MR, Laing NG, Goldfarb LG: Dominant mutations in KBTBD13, a member of the BTB/Kelch family, cause nemaline myopathy with cores. Am J Hum Genet 2010, 87:842-847.

22. Gupta VA, Ravenscroft G, Shaheen R, Todd EJ, Swanson LC, Shiina M, Ogata K, Hsu C, Clarke NF, Darras BT, Farrar MA, Hashem A, Manton ND, Muntoni F, North KN, Sandaradura SA, Nishino I, Hayashi YK, Sewry CA, Thompson EM, Yau KS, Brownstein CA, Yu TW, Allcock RJ, Davis MR, Wallgren-Pettersson C, Matsumoto N, Alkuraya FS, Laing NG, Beggs AH: Identification of KLHL41 mutations implicates BTB-Kelch-mediated ubiquitination as an alternate pathway to myofibrillar disruption in nemaline myopathy. Am J Hum Genet 2013, 93:1108-1117.

23. Adams J, Kelso R, Cooley L: The kelch repeat superfamily of proteins: propellers of cell function. Trends Cell Biol 2000, 10:17-24.

24. Dhanoa BS, Cogliati T, Satish AG, Bruford EA, Friedman JS: Update on the Kelch-like (KLHL) gene family. Hum Genomics 2013, 7:13.

25. Nacak TG, Alajati A, Leptien K, Fulda C, Weber H, Miki T, Czepluch FS, Waltenberger J, Wieland T, Augustin HG, Kroll J: The BTB-Kelch protein KLEIP controls endothelial migration and sprouting angiogenesis. Circ Res 2007, 100:1155-1163.

26. Neuhaus $P$, Jaschinsky B, Schneider $S$, Neuhaus H, Wolter A, Ebelt H, Braun T: Overexpression of Kelch domain containing-2 (mKlhdc2) inhibits differentiation and directed migration of $\mathrm{C} 2 \mathrm{C} 12$ myoblasts. Exp Cell Res 2006, 312:3049-3059.

27. Luhrig S, Kolb S, Mellies N, Nolte J: The novel BTB-kelch protein, KBTBD8, is located in the Golgi apparatus and translocates to the spindle apparatus during mitosis. Cell Div 2013, 8:3.

28. Shibata S, Zhang J, Puthumana J, Stone KL, Lifton RP: Kelch-like 3 and Cullin 3 regulate electrolyte homeostasis via ubiquitination and degradation of WNK4. Proc Natl Acad Sci U S A 2013, 110:7838-7843.

29. Yu W, Li Y, Zhou X, Deng Y, Wang Z, Yuan W, Li D, Zhu C, Zhao X, Mo X, Huang W, Luo N, Yan Y, Ocorr K, Bodmer R, Wang Y, Wu X: A novel human BTB-kelch protein KLHL31, strongly expressed in muscle and heart, inhibits transcriptional activities of TRE and SRE. Mol Cells 2008, 26:443-453.

30. Strutt H, Searle E, Thomas-Macarthur V, Brookfield R, Strutt D: A Cul-3-BTB ubiquitylation pathway regulates junctional levels and asymmetry of core planar polarity proteins. Development 2013, 140:1693-1702.

31. Marshall J, Blair LA, Singer JD: BTB-Kelch proteins and ubiquitination of kainate receptors. Adv Exp Med Biol 2011, 717:115-125.
32. More VR, Xu J, Shimpi PC, Belgrave C, Luyendyk JP, Yamamoto M, Slitt AL: Keap1 knockdown increases markers of metabolic syndrome after long-term high fat diet feeding. Free Radic Biol Med 2013, 61C:85-94.

33. Velichkova M, Guttman J, Warren C, Eng L, Kline K, Vogl AW, Hasson T: A human homologue of Drosophila kelch associates with myosin-VIla in specialized adhesion junctions. Cell Motil Cytoskeleton 2002, 51:147-164.

34. Abou-Elhamd A, Cooper O, Munsterberg A: Klhl31 is associated with skeletal myogenesis and its expression is regulated by myogenic signals and Myf-5. Mech Dev 2009, 126:852-862.

35. Matsudo Y, Takamori Y, Fujimura L, Nishio S, Sasagawa K, Komuro I, Tokuhisa T, Hatano M: Overexpression of Nd1, a novel Kelch family protein, in the heart of transgenic mice protects against doxorubicin-induced cardiomyopathy. Transgenic Res 2006, 15:573-581.

36. Fujimura L, Matsudo Y, Kang M, Takamori Y, Tokuhisa T, Hatano M: Protective role of $\mathrm{Nd} 1$ in doxorubicin-induced cardiotoxicity. Cardiovasc Res 2004, 64:315-321.

37. Bowlin KM, Embree L, Garry MG, Garry DJ, Shi X: Kbtbd5 is regulated by MyoD and restricted to the myogenic lineage. Differentiation 2013, 86:184-191.

38. du Puy L, Beqqali A, van Tol HT, Monshouwer-Kloots J, Passier R, Haagsman HP, Roelen BA: Sarcosin (Krp1) in skeletal muscle differentiation: gene expression profiling and knockdown experiments. Int J Dev Biol 2012, 56:301-309.

39. Greenberg CC, Connelly PS, Daniels MP, Horowits R: Krp1 (Sarcosin) promotes lateral fusion of myofibril assembly intermediates in cultured mouse cardiomyocytes. Exp Cell Res 2008, 314:1177-1191.

40. Adams JC, Seed B, Lawler J: Muskelin, a novel intracellular mediator of cell adhesive and cytoskeletal responses to thrombospondin-1. Embo J 1998, 17:4964-4974.

41. Tagnaouti N, Loebrich S, Heisler F, Pechmann Y, Fehr S, De Arcangelis A, Georges-Labouesse E, Adams JC, Kneussel M: Neuronal expression of muskelin in the rodent central nervous system. BMC Neurosci 2007, 8:28.

42. Chin KT, Xu HT, Ching YP, Jin DY: Differential subcellular localization and activity of kelch repeat proteins KLHDC1 and KLHDC2. Mol Cell Biochem 2007, 296:109-119.

43. Sekine $\mathrm{Y}$, Hatanaka R, Watanabe T, Sono N, lemura S, Natsume T, Kuranaga E, Miura M, Takeda K, Ichijo H: The Kelch repeat protein KLHDC10 regulates oxidative stress-induced ASK1 activation by suppressing PP5. Mol Cell 2012, 48:692-704.

44. Chen WL, Lin JW, Huang HJ, Wang SM, Su MT, Lee-Chen GJ, Chen CM, Hsieh-Li HM: SCA8 mRNA expression suggests an antisense regulation of KLHL1 and correlates to SCA8 pathology. Brain Res 2008, 1233:176-184.

45. Bomont P, Cavalier L, Blondeau F, Ben Hamida C, Belal S, Tazir M, Demir E, Topaloglu H, Korinthenberg R, Tuysuz B, Landrieu P, Hentati F, Koenig M: The gene encoding gigaxonin, a new member of the cytoskeletal BTB/ kelch repeat family, is mutated in giant axonal neuropathy. Nat Genet 2000, 26:370-374.

46. Ganay T, Boizot A, Burrer R, Chauvin JP, Bomont P: Sensory-motor deficits and neurofilament disorganization in gigaxonin-null mice. Mol Neurodegener 2011, 6:25.

47. Puente XS, Pinyol M, Quesada V, Conde L, Ordonez GR, Villamor N Escaramis G, Jares P, Bea S, Gonzalez-Diaz M, Bassaganyas L, Baumann T, Juan M, Lopez-Guerra M, Colomer D, Tubio JM, Lopez C, Navarro A, Tornador C, Aymerich M, Rozman M, Hernandez JM, Puente DA, Freije JM, Velasco G, Gutierrez-Fernandez A, Costa D, Carrio A, Guijarro S, Enjuanes A, et al: Whole-genome sequencing identifies recurrent mutations in chronic lymphocytic leukaemia. Nature 2011, 475:101-105.

48. Kroll J, Shi X, Caprioli A, Liu HH, Waskow C, Lin KM, Miyazaki T, Rodewald HR, Sato TN: The BTB-kelch protein KLHL6 is involved in B-lymphocyte antigen receptor signaling and germinal center formation. Mol Cell Biol 2005, 25:8531-8540.

49. Li QK, Singh A, Biswal S, Askin F, Gabrielson E: KEAP1 gene mutations and NRF2 activation are common in pulmonary papillary adenocarcinoma. J Hum Genet 2011, 56:230-234.

50. Wakabayashi N, Itoh K, Wakabayashi J, Motohashi H, Noda S, Takahashi S, Imakado S, Kotsuji T, Otsuka F, Roop DR, Harada T, Engel JD, Yamamoto M: Keap1-null mutation leads to postnatal lethality due to constitutive Nrf2 activation. Nat Genet 2003, 35:238-245.

51. Yuan WC, Lee YR, Huang SF, Lin YM, Chen TY, Chung HC, Tsai CH, Chen HY, Chiang CT, Lai CK, Lu LT, Chen CH, Gu DL, Pu YS, Jou YS, Lu KP, Hsiao PW, Shih HM, Chen RH: A Cullin3-KLHL20 Ubiquitin ligase-dependent pathway targets PML to potentiate HIF-1 signaling and prostate cancer progression. Cancer Cell 2011, 20:214-228. 
52. Hara T, Ishida H, Raziuddin R, Dorkhom S, Kamijo K, Miki T: Novel kelch-like protein, KLEIP, is involved in actin assembly at cell-cell contact sites of Madin-Darby canine kidney cells. Mol Biol Cell 2004, 15:1172-1184.

53. Liang $X Q$, Avraham HK, Jiang S, Avraham S: Genetic alterations of the NRP/B gene are associated with human brain tumors. Oncogene 2004, 23:5890-5900

54. Garcia-Calero E, Puelles L: Pallial expression of Enc1 RNA in postnatal mouse telencephalon. Brain Res Bull 2005, 66:445-448.

55. Salipante SJ, Mealiffe ME, Wechsler J, Krem MM, Liu Y, Namkoong S, Bhagat G, Kirchhoff T, Offit K, Lynch H, Wiernik PH, Roshal M, McMaster ML, Tucker M, Fromm JR, Goldin LR, Horwitz MS: Mutations in a gene encoding a midbody kelch protein in familial and sporadic classical Hodgkin lymphoma lead to binucleated cells. Proc Natl Acad Sci U S A 2009, 106:14920-14925.

56. Louis-Dit-Picard H, Barc J, Trujillano D, Miserey-Lenkei S, Bouatia-Naji N, Pylypenko O, Beaurain G, Bonnefond A, Sand O, Simian C, Vidal-Petiot E, Soukaseum C, Mandet C, Broux F, Chabre O, Delahousse M, Esnault V, Figuet B, Houillier P, Bagnis Cl, Koenig J, Konrad M, Landais P, Mourani C, Niaudet P, Probst V, Thauvin C, Unwin RJ, Soroka SD, Ehret G, et al: KLHL3 mutations cause familial hyperkalemic hypertension by impairing ion transport in the distal nephron. Nat Genet 2012,44:456-460. S1-3.

57. Friedman JS, Ray JW, Waseem N, Johnson K, Brooks MJ, Hugosson T, Breuer D, Branham KE, Krauth DS, Bowne SJ, Sullivan LS, Ponjavic V, Granse L, Khanna R, Trager EH, Gieser LM, Hughbanks-Wheaton D, Cojocaru RI Ghiasvand NM, Chakarova CF, Abrahamson M, Goring HH, Webster AR, Birch DG, Abecasis GR, Fann Y, Bhattacharya SS, Daiger SP, Heckenlively JR Andreasson S, et al: Mutations in a BTB-Kelch protein, KLHL7, cause autosomal-dominant retinitis pigmentosa. Am J Hum Genet 2009, 84:792-800.

58. Yatsenko AN, Roy A, Chen R, Ma L, Murthy LJ, Yan W, Lamb DJ, Matzuk MM: Non-invasive genetic diagnosis of male infertility using spermatozoal RNA: KLHL10 mutations in oligozoospermic patients impair homodimerization. Hum Mol Genet 2006, 15:3411-3419.

59. Qiu QM, Liu G, Li WN, Shi QW, Zhu FX, Lu GX: [Mutation of KLHL-10 in idiopathic infertile males with azoospermia, oligospermia or asthenospermia]. Zhonghua Nan Ke Xue 2009, 15:974-979.

60. Yan W, Ma L, Burns KH, Matzuk MM: Haploinsufficiency of kelch-like protein homolog 10 causes infertility in male mice. Proc Natl Acad Sci U S A 2004, 101:7793-7798.

61. Stogios PJ, Prive GG: The BACK domain in BTB-kelch proteins. Trends Biochem Sci 2004, 29:634-637.

62. Albagli O, Dhordain P, Deweindt C, Lecocq G, Leprince D: The BTB/POZ domain: a new protein-protein interaction motif common to DNA- and actin-binding proteins. Cell Growth Differ 1995, 6:1193-1198.

63. Collins T, Stone JR, Williams AJ: All in the family: the BTB/POZ, KRAB, and SCAN domains. Mol Cell Biol 2001, 21:3609-3615.

64. Perez-Torrado R, Yamada D, Defossez PA: Born to bind: the BTB protein-protein interaction domain. Bioessays 2006, 28:1194-1202.

65. Zipper LM, Mulcahy RT: The Keap1 BTB/POZ dimerization function is required to sequester Nrf2 in cytoplasm. J Biol Chem 2002, 277:36544-36552.

66. Sambuughin N, Swietnicki W, Techtmann S, Matrosova V, Wallace T, Goldfarb L, Maynard E: KBTBD13 interacts with Cullin 3 to form a functional ubiquitin ligase. Biochem Biophys Res Commun 2012, 421:743-749.

67. Geyer R, Wee S, Anderson S, Yates J, Wolf DA: BTB/POZ domain proteins are putative substrate adaptors for cullin 3 ubiquitin ligases. Mol Cell 2003, 12:783-790

68. Canning P, Cooper CD, Krojer T, Murray JW, Pike AC, Chaikuad A, Keates T, Thangaratnarajah C, Hojzan V, Marsden BD, Gileadi O, Knapp S, von Delft F, Bullock N: Structural basis for Cul3 protein assembly with the BTB-Kelch family of E3 ubiquitin ligases. J Biol Chem 2013, 288:7803-7814.

69. Liu Q, Yao F, Wang M, Zhou B, Cheng H, Wang W, Jin L, Lin Q, Wang JC: Novel human BTB/POZ domain-containing zinc finger protein ZBTB1 inhibits transcriptional activities of CRE. Mol Cell Biochem 2011, 357:405-414.

70. Korutla $L$, Wang $P$, Jackson TG, Mackler SA: NAC1, a POZ/BTB protein that functions as a corepressor. Neurochem Int 2009, 54:245-252.

71. Choe S, Cushman S, Baker KA, Pfaffinger P: Excitability is mediated by the T1 domain of the voltage-gated potassium channel. Novartis Found Symp 2002, 245:169-175. discussion 175-167, 261-164.

72. Aravind L, Koonin EV: Fold prediction and evolutionary analysis of the POZ domain: structural and evolutionary relationship with the potassium channel tetramerization domain. J Mol Biol 1999, 285:1353-1361.
73. Udd B: Distal myopathies-new genetic entities expand diagnostic challenge. Neuromuscul Disord 2012, 22:5-12.

74. Furukawa $\mathrm{M}, \mathrm{He}$ YJ, Borchers $\mathrm{C}$, Xiong Y: Targeting of protein ubiquitination by BTB-Cullin 3-Roc1 ubiquitin ligases. Nat Cell Biol 2003, 5:1001-1007.

75. Sumara I, Quadroni M, Frei C, Olma MH, Sumara G, Ricci R, Peter M: A Cul3-based E3 ligase removes Aurora B from mitotic chromosomes, regulating mitotic progression and completion of cytokinesis in human cells. Dev Cell 2007, 12:887-900

76. Sihag RK, Inagaki M, Yamaguchi T, Shea TB, Pant HC: Role of phosphorylation on the structural dynamics and function of types III and IV intermediate filaments. Exp Cell Res 2007, 313:2098-2109.

77. Sanoudou D, Beggs AH: Clinical and genetic heterogeneity in nemaline myopathy-a disease of skeletal muscle thin filaments. Trends Mol Med 2001, 7:362-368.

78. Zhang DD, Lo SC, Sun Z, Habib GM, Lieberman MW, Hannink M: Ubiquitination of Keap1, a BTB-Kelch substrate adaptor protein for Cul3 targets Keap1 for degradation by a proteasome-independent pathway. J Biol Chem 2005, 280:30091-30099.

79. Blandin G, Marchand S, Charton K, Daniele N, Gicquel E, Boucheteil JB, Bentaib A, Barrault L, Stockholm D, Bartoli M, Richard I: A human skeletal muscle interactome centered on proteins involved in muscular dystrophies: LGMD interactome. Skelet Muscle 2013, 3:3.

80. Spence HJ, Johnston I, Ewart K, Buchanan SJ, Fitzgerald U, Ozanne BW Krp1, a novel kelch related protein that is involved in pseudopod elongation in transformed cells. Oncogene 2000, 19:1266-1276.

81. Wallgren-Pettersson C, Sewry CA, Nowak KJ, Laing NG: Nemaline myopathies. Semin Pediatr Neurol 2011, 18:230-238.

82. Bradley PL, Andrew DJ: ribbon encodes a novel BTB/POZ protein required for directed cell migration in Drosophila melanogaster. Development 2001, 128:3001-3015.

83. Valiyaveettil M, Bentley AA, Gursahaney P, Hussien R, Chakravarti R, Kureishy N, Prag S, Adams JC: Novel role of the muskelin-RanBP9 complex as a nucleocytoplasmic mediator of cell morphology regulation. J Cell Biol 2008, 182:727-739

84. Hudson AM, Cooley L: Drosophila Kelch functions with Cullin-3 to organize the ring canal actin cytoskeleton. J Cell Bio/ 2010 188:29-37.

85. Sasagawa K, Matsudo Y, Kang M, Fujimura L, litsuka Y, Okada S, Ochiai T, Tokuhisa T, Hatano M: Identification of Nd1, a novel murine kelch family protein, involved in stabilization of actin filaments. J Biol Chem 2002, 277:44140-44146.

86. Paxton CW, Cosgrove RA, Drozd AC, Wiggins EL, Woodhouse S, Watson RA Spence HJ, Ozanne BW, Pell JM: BTB-Kelch protein Krp1 regulates proliferation and differentiation of myoblasts. Am J Physiol Cell Physiol 2011, 300:C1345-C1355.

87. Philips J, Herskowitz I: Identification of Kel1p, a kelch domain-containing protein involved in cell fusion and morphology in Saccharomyces cerevisiae. J Cell Biol 1998, 143:375-389.

88. Zhang M, An C, Gao Y, Leak RK, Chen J, Zhang F: Emerging roles of Nrf2 and phase II antioxidant enzymes in neuroprotection. Prog Neurobiol 2013, 100:30-47

89. Miller CJ, Gounder SS, Kannan S, Goutam K, Muthusamy VR, Firpo MA, Symons JD, Paine R 3rd, Hoidal JR, Rajasekaran NS: Disruption of Nrf2/ARE signaling impairs antioxidant mechanisms and promotes cell degradation pathways in aged skeletal muscle. Biochim Biophys Acto 2012, 1822:1038-1050

90. Metzger T, Kleiss C, Sumara I: CUL3 and protein kinases: Insights from PLK1/KLHL22 interaction. Cell Cycle 2013, 12:2291-2296.

91. Wakabayashi M, Mori T, Isobe K, Sohara E, Susa K, Araki Y, Chiga M, Kikuchi E, Nomura N, Mori Y, Matsuo H, Murata T, Nomura S, Asano T, Kawaguchi H, Nonoyama S, Rai T, Sasaki S, Uchida S: Impaired KLHL3-mediated ubiquitination of WNK4 causes human hypertension. Cell Rep 2013, 3:858-868.

92. Boyden LM, Choi M, Choate KA, Nelson-Williams CJ, Farhi A, Toka HR, Tikhonova IR, Bjornson R, Mane SM, Colussi G, Lebel M, Gordon RD, Semmekrot BA, Poujol A, Valimaki MJ, De Ferrari ME, Sanjad SA, Gutkin M, Karet FE, Tucci JR, Stockigt JR, Keppler-Noreuil KM, Porter CC, Anand SK, Whiteford ML, Davis ID, Dewar SB, Bettinelli A, Fadrowski JJ, Belsha CW et al: Mutations in kelch-like 3 and cullin 3 cause hypertension and electrolyte abnormalities. Nature 2012, 482:98-102. 
93. Lee YR, Yuan WC, Ho HC, Chen $\mathrm{CH}$, Shih HM, Chen RH: The Cullin 3 substrate adaptor KLHL20 mediates DAPK ubiquitination to control interferon responses. Embo J 2010, 29:1748-1761.

94. Rondou P, Haegeman G, Vanhoenacker P, Van Craenenbroeck K: BTB Protein KLHL12 targets the dopamine D4 receptor for ubiquitination by a Cul3-based E3 ligase. J Biol Chem 2008, 283:11083-11096.

95. Goll DE, Neti G, Mares SW, Thompson VF: Myofibrillar protein turnover: the proteasome and the calpains. J Anim Sci 2008, 86:E19-E35.

96. Sorimachi $\mathrm{H}$, Ono Y: Regulation and physiological roles of the calpain system in muscular disorders. Cardiovasc Res 2012, 96:11-22.

97. Primeau AJ, Adhihetty PJ, Hood DA: Apoptosis in heart and skeletal muscle. Can J Appl Physiol 2002, 27:349-395.

98. Tews DS: Apoptosis and muscle fibre loss in neuromuscular disorders. Neuromuscul Disord 2002, 12:613-622.

99. Banerjee A, Guttridge DC: Mechanisms for maintaining muscle. Curr Opin Support Palliat Care 2012, 6:451-456.

100. Murton AJ, Constantin D, Greenhaff PL: The involvement of the ubiquitin proteasome system in human skeletal muscle remodelling and atrophy. Biochim Biophys Acta 2008, 1782:730-743.

101. Attaix D, Ventadour S, Codran A, Bechet D, Taillandier D, Combaret L: The ubiquitin-proteasome system and skeletal muscle wasting. Essays Biochem 2005, 41:173-186.

102. Bonaldo P, Sandri M: Cellular and molecular mechanisms of muscle atrophy. Dis Model Mech 2013, 6:25-39.

103. Sandri M: Autophagy in skeletal muscle. FEBS Lett 2010, 584:1411-1416.

104. Richard I, Roudaut C, Saenz A, Pogue R, Grimbergen JE, Anderson LV, Beley C, Cobo AM, de Diego C, Eymard B, Gallano P, Ginjaar HB, Lasa A, Pollitt C, Topaloglu H, Urtizberea JA, de Visser M, van der Kooi A, Bushby K, Bakker E, Lopez de Munain A, Fardeau M, Beckmann JS: Calpainopathy-a survey of mutations and polymorphisms. Am J Hum Genet 1999, 64:1524-1540.

105. Furukawa M, Xiong Y: BTB protein Keap1 targets antioxidant transcription factor Nrf2 for ubiquitination by the Cullin 3-Roc1 ligase. Mol Cell Biol 2005, 25:162-171.

106. Tseng LA, Bixby JL: Interaction of an intracellular pentraxin with a BTB-Kelch protein is associated with ubiquitylation, aggregation and neuronal apoptosis. Mol Cell Neurosci 2011, 47:254-264.

107. Willis MS, Patterson C: Into the heart: the emerging role of the ubiquitin-proteasome system. J Mol Cell Cardiol 2006, 41:567-579.

108. Nandi D, Tahiliani P, Kumar A, Chandu D: The ubiquitin-proteasome system. J Biosci 2006, 31:137-155.

109. Pickart CM: Mechanisms underlying ubiquitination. Annu Rev Biochem 2001, 70:503-533.

110. Deshaies RJ, Joazeiro CA: RING domain E3 ubiquitin ligases. Annu Rev Biochem 2009, 78:399-434

111. Rotin D, Kumar S: Physiological functions of the HECT family of ubiquitin ligases. Nat Rev Mol Cell Biol 2009, 10:398-409.

112. Marin I: Diversification of the cullin family. BMC Evol Biol 2009, 9:267.

113. Sarikas A, Hartmann T, Pan ZQ: The cullin protein family. Genome Biol 2011, $12: 220$.

114. Singer JD, Gurian-West M, Clurman B, Roberts JM: Cullin-3 targets cyclin E for ubiquitination and controls $\mathrm{S}$ phase in mammalian cells. Genes Dev 1999, 13:2375-2387

115. Comi GP, Fortunato F, Lucchiari S, Bordoni A, Prelle A, Jann S, Keller A, Ciscato P, Galbiati S, Chiveri L, Torrente Y, Scarlato G, Bresolin N: Beta-enolase deficiency, a new metabolic myopathy of distal glycolysis. Ann Neurol 2001, 50:202-207.

116. Moreira ES, Wiltshire TJ, Faulkner G, Nilforoushan A, Vainzof M, Suzuki OT, Valle G, Reeves R, Zatz M, Passos-Bueno MR, Jenne DE: Limb-girdle muscular dystrophy type $2 \mathrm{G}$ is caused by mutations in the gene encoding the sarcomeric protein telethonin. Nat Genet 2000, 24:163-166.

117. Duncan DR, Kang PB, Rabbat JC, Briggs CE, Lidov HG, Darras BT, Kunkel LM: A novel mutation in two families with limb-girdle muscular dystrophy type 2C. Neurology 2006, 67:167-169.

118. Chernorudskiy AL, Gainullin MR: Ubiquitin system: direct effects join the signaling. Sci Signal 2013, 6:pe22

119. Karin M, Ben-Neriah Y: Phosphorylation meets ubiquitination: the control of NF-[kappa]B activity. Annu Rev Immunol 2000, 18:621-663.

120. Ohkoshi A, Suzuki T, Ono M, Kobayashi T, Yamamoto M: Roles of Keap1-Nrf2 system in upper aerodigestive tract carcinogenesis. Cancer Prev Res (Phila) 2013, 6:149-159.
121. Ohta Y, Fujimura L, Nishio S, Arima M, Sakamoto A, Shimada H, Ochiai T, Tokuhisa T, Hatano M: A kelch family protein Nd1-L functions as a metastasis suppressor in cancer cells via Rho family proteins mediated mechanism. Int J Oncol 2010, 36:427-434.

122. Bredholt G, Storstein A, Haugen M, Krossnes BK, Husebye E, Knappskog P, Vedeler CA: Detection of autoantibodies to the BTB-kelch protein KLHL7 in cancer sera. Scand J Immunol 2006, 64:325-335.

123. Nemes JP, Benzow KA, Moseley ML, Ranum LP, Koob MD: The SCA8 transcript is an antisense RNA to a brain-specific transcript encoding a novel actin-binding protein (KLHL1). Hum Mol Genet 2000, 9:1543-1551.

124. He Y, Zu T, Benzow KA, Orr HT, Clark HB, Koob MD: Targeted deletion of a single Sca8 ataxia locus allele in mice causes abnormal gait, progressive loss of motor coordination, and Purkinje cell dendritic deficits. J Neurosci 2006, 26:9975-9982.

125. Bruno C, Bertini E, Federico A, Tonoli E, Lispi ML, Cassandrini D, Pedemonte M, Santorelli FM, Filocamo M, Dotti MT, Schenone A, Malandrini A, Minetti C: Clinical and molecular findings in patients with giant axonal neuropathy (GAN). Neurology 2004, 62:13-16.

126. Ding J, Allen E, Wang W, Valle A, Wu C, Nardine T, Cui B, Yi J, Taylor A, Jeon NL, Chu S, So Y, Vogel H, Tolwani R, Mobley W, Yang Y: Gene targeting of GAN in mouse causes a toxic accumulation of microtubule-associated protein 8 and impaired retrograde axonal transport. Hum Mol Genet 2006, 15:1451-1463.

doi:10.1186/2044-5040-4-11

Cite this article as: Gupta and Beggs: Kelch proteins: emerging roles in skeletal muscle development and diseases. Skeletal Muscle 2014 4:11.

\section{Submit your next manuscript to BioMed Central and take full advantage of:}

- Convenient online submission

- Thorough peer review

- No space constraints or color figure charges

- Immediate publication on acceptance

- Inclusion in PubMed, CAS, Scopus and Google Scholar

- Research which is freely available for redistribution 